\title{
Seyyid Vehbî Divanı'na göre 18. yüzyılda Osmanlı Bahriye Teşkilatı
}

\section{Özlem DÜZLÜ2}

\begin{abstract}
APA: Düzlü, Ö. (2019). Seyyid Vehbî Divanı’na göre 18. yüzyılda Osmanlı Bahriye Teşkilatı. RumeliDE Dil ve Edebiyat Araşttrmaları Dergisi, (17), 134-153. DOI: 10.2900o/rumelide.656661
\end{abstract}

\section{$\ddot{\mathbf{O} z}$}

Klasik Türk şiirinin muhtevası dâhilindeki alanlardan biri de Osmanlı denizciliğidir. Klasik Türk şairleri bahriye teşkilatına ait mekânlar, bu mekânlardaki binaların yapımı/tamiri, gemileri denize indirme, atama gibi tanıklık ettikleri tarihî olaylar yanında benzetme ve hayallerinde kullandıkları çeşitli unsurlarla bahriye teşkilatıyla ilgili birtakım bilgi ve özellikleri şiirlerine yansıtmışlardır. III. Ahmed ve I. Mahmud dönemlerinin pek çok gelişmesini divanına yansıtan Seyyid Vehbî de (ö. 1736) gemiyi denize indirme törenleri, tersaneye ait binaların restorasyonu gibi özellikle Lale Devri’ndeki bazı tarihî gelişmeler ile Osmanlı Bahriye Teşkilatında yer alan gemiler, teşkilatı oluşturan şahıslar ve pek çok denizcilik terim ve tabirine şiirlerinde yer vermiştir. Bu makalede Seyyid Vehbî Divanı örnekleminde Osmanlı Bahriye Teşkilatıyla ilgili bazı gelişme ve unsurların klasik Türk şiirine nasıl yansıdığı ortaya konmaya çalışılmıştır. Makalede Osmanlı bahriyesi; Tersane-i Âmire, Osmanlı Bahriyesinde Kullanılan Gemiler, Bahriye Mensupları, Donanmanın Denize/Sefere Çıkması ve Gemilerin Denize İndirilmesi olmak üzere beş başlık altında incelenmiştir.

Anahtar kelimeler: Bahriye teşkilatı, Seyyid Vehbî Divanı, klasik Türk şiiri.

\section{$1^{\text {th }}$ century Ottoman navy organization according to Seyyid Vehbî's Divan}

\begin{abstract}
One of the fields that Classical Turkish Poetry covers is Ottoman Navy. Classical Turkish Poets witnessed some places belonging to the navy and some historical events concerning the navy like construction/repair of buildings in such places, ship launching, and appointments and combined these with metaphors and numerous components from their imaginations and, in this way, reflected some information and features about the navy on their poems. In his poems, Seyyid Vehbî (died in 1736), who reflected many developments of the periods of Ahmed III and Mahmut I, included many historical events, especially in Tulip Era, like ship launching ceremonies, restoration of shipbuilding yard and also ships in the Ottoman Navy, some officers and numerous navy terms. Via Seyyid Vehbî's Divan example, this study aims to show how various improvements and elements belonging to Ottoman Navy and naval terms are reflected on classical Turkish Poetry. In this study, the Ottoman Navy was examined under the titles of Tersane-i Âmire, ships used in Ottoman Navy, naval officers, Ottoman Navy take action for war, launching of ships.
\end{abstract}

Keywords: Navy, Seyyid Vehbî’s Divan, classical Turkish poetry.

\footnotetext{
1 Bu çalıșma Prof. Dr. İsmail GÜLEÇ danıșmanlığında hazırlanan “Seyyid Vehbî Divanı’na Göre 18. Asırda Osmanlılarda Sosyal Hayat" (Sakarya Üniversitesi SBE, 2018) adlı doktora tezinden üretilmiştir. Ayrıca çalışma 1-3 Aralık 2016 tarihlerinde Manisa'da düzenlenen“Uluslararası; Fethinin 500. Yılında Cezayir, Barbaros Hayrettin Paşa ve Osmanlı Denizciliği Sempozyumu”nda sunulan bildirinin gözden geçirilmiş ve yeniden düzenlenmiş hâlidir.

2 Öğr. Gör. Dr., Sakarya Üniversitesi, Rektörlük Türk Dili Bölümü (Sakarya, Türkiye), oduzlu@sakarya.edu.tr, ORCID.ID: o000-0001-9305-4371 [Makale kayit tarihi: 09.10.2019-kabul tarihi: 20.12.2019; DOI: 10.29000/rumelide.656661]
} 


\section{Giriş}

Klasik Türk şiiri; âdet ve inanışlarından gündelik yaşantısına, tarihî şahsiyet ve olaylardan kurumlarına kadar Osmanlı toplumunun yaşantısından izler barındırır. Bu izlerin rastlandığı alanlardan biri de denizcilik ve Osmanlı denizciliğidir. Denizcilik terim ve tabirlerine teşbih ve hayallerinde sıklıkla yer veren klasik Türk şairleri bazen de Osmanlı bahriyesiyle ilgili hususları çeşitli vesilelerle şiirlerine dâhil etmişlerdir. Şairler, kimi zaman tanıklık ettikleri tarihî olayları şiirlerine konu edinirken kimi zamanda bahriyeyle ilgili unsur ve uygulamaları değişik çağrışımlarla duygu ve hayallerini ifade etmenin bir vasıtası olarak kullanmışlardır.

Lale Devri başta olmak üzere III. Ahmed ve I. Mahmud dönemlerinin pek çok gelişmesini divanına yansitan Seyyid Vehbî (ö. 1736) de denizcilik terim ve tabirleri ile Osmanlı Bahriye Teşkilatıyla ilgili birtakım gelişme, unsur ve uygulamaları şiirlerinde söz konusu etmiştir. Divanda daha ziyade, Osmanlı'da her alanda yeniden canlanma ve yoğun bir hareketliliğin yaşandığı, Lale Devri'nin denizcilikle ilgili gelişmelerine yer veren Seyyid Vehbî, Osmanlı Bahriye Teşkilatında gerçekleşen atamalar, gemiyi denize indirme törenleri ve tersaneye ait binaların restorasyonu gibi bazı hadiseleri konu alan manzumeler yanında bu teşkilat dâhilindeki mekânlar, gemiler, teşkilatı oluşturan şahıs ve uygulamaların yer aldığı beyit ve bentler de kaleme almıştır. Bu çalışmada Osmanlı denizciliğiyle ilgili gelişmelere çă̆daşı şairlere göre nispeten daha fazla yer veren Seyyid Vehbî’nin divanı örnekleminde Lale Devri'nde Osmanlı Bahriye Teşkilatıyla ilgili birtakım gelişme ve unsurların klasik Türk şiirine yansıması ele alınmıştır. Çalışmada Osmanlı bahriyesi; Tersane-i Âmire, Osmanlı Bahriyesinde Kullanılan Gemiler, Bahriye Mensupları, Donanmanın Denize/Sefere Çıkması ve Gemilerin Denize İndirilmesi başlıkları altında incelenmiştir.

\section{Osmanlı Bahriyesi}

Osmanlı Devleti kurulup sınırları Ege, Akdeniz ve Karadeniz sahillerine ulaşınca donanmaya olan ihtiyaç artmıştır (Uzunçarşıll, 1988: 389). Batı Anadolu sahillerinde kurulmuş olan ve kendilerine öncülük eden Menteşe, Aydın, Saruhan ve Karasi beyliklerinden tevarüs ettikleri donanmadan ve denizcilerden yararlanma yoluna giden Osmanlılar, donanmasını Orhan Bey zamanında özellikle Karasi Beyliği'nin mevcut donanmasına dayalı olarak yavaş yavaş büyütmüşsür (Bostan, 2007: 3). İlk zamanlarda Edincik, Gemlik, Karamürsel ve İzmit'te kurulan tersanelerin ardından Rumeliye yerleştikten sonra Gelibolu'da bir tersane meydana getirilmiştir (Uzunçarşıll, 1988: 390). Bu dönemde Osmanlı denizciliği üzerinde Venedik ve Ceneviz gibi iki büyük İtalyan şehir devletinin deniz teknolojisi ve personel takviyesi bakımından önemli etkisi olmuştur (Bostan, 2007: 5). Bununla birlikte henüz bir akın donanması hüviyetinde olan Osmanlı donanmasının akın faaliyetinden çıkıp yavaş yavaş deniz aşırı fetihler için hazırlanması Fatih Sultan Mehmed dönemine rastlamaktadır. İstanbul'un fethinden sonra tersaneyi önce Kadırga Limanı'na, daha sonra Haliç'e naklettirerek kurduğu yeni gözler (gemi inşaat tezgâhları) ile güçlü bir donanma meydana getirmeye büyük önem veren Fatih, Venediklilere karşı kuvvetli bir deniz gücünün gerekli olduğunu anlamış, Çanakkale Boğaz’ı etrafındaki bazı adalarla Ege denizindeki birtakım adaları zapt ederek sahillerin emniyetini sağlamıştır. Karadeniz’in bir Türk gölü hâline getirildiği, 1481 'de Gedik Ahmed Paşa komutasındaki Osmanlı donanmasının Otronto'yu zapt ettiği bu dönemde Türk deniz gücü yine de istenilen seviyeye gelememiş, savaş gemileri henüz denizci Batılı devletler seviyesine ulaşamamıştır. Osmanlı Devleti'nin Yakındoğu ve Doğu Akdeniz'de yükselişe geçtiği ve Türk denizciliğinin cihanşümul bir gelişme göstermeye başladığı II. Bayezid devrinde Osmanlı donanması yeni baştan teşkilatlandırılmıştır. II. Bayezid'in deniz stratejisi daha sonra oğlu I. Selim tarafından da sürdürülmüştür. Tersanenin genişletilmesi hususunun da ele alındı̆̆ bu dönemin 
ardından Kanunî Sultan Süleyman zamanında Osmanlı bahriyesi her alanda Avrupa'nın denizci devletlerinden daha üstün bir duruma gelmiştir. Barbaros Hayreddin Paşa, Turgut Reis ve Kılıç Ali Paşa'nın kaptan paşalık yaptığı donanmanın en parlak döneminde Karadeniz'in ardından Kızıldeniz ve Akdeniz'de de hâkimiyet sağlanmıştır. 17. yüzyılın başlarından itibaren denizcilik bilgisi olmayan kaptan paşaların idaresi ve kürekli Osmanlı donanmasının gemicilikteki yeni teknik gelişmelere ayak uyduramaması onu eski gücünden uzaklaştırmıştır (Gencer, 1991: 503-506). Fakat bu asrın sonlarından itibaren donanmada kalyonların ve başka bazı yelkenli gemilerin artmasına ehemmiyet verilmesi ve 18 . asır başlarında Mezomorto Hüseyin Paşa'nın Osmanlı donanmasını düzene sokması ile tekrar Türklere geçen Akdeniz hâkimiyeti 1770 yılında meydana gelen Çeşme faciasına kadar devam etmiştir (Uzunçarşıll, 1988: 393; Gencer, 1991: 506). 18. yüzyılın başlarında III. Ahmed ile yeniden toparlanma dönemine giren Osmanlı'nın denizlerde de başarılar elde ettiği bu dönemde (Bostan, 2007: 53) Osmanlı bahriyesindeki toparlanmanın Seyyid Vehbî Divanı'na yansıması daha çok Tersane'de yapılan restorasyonlar ile gemi inşa faaliyetleri açısından olmuştur.

\section{Tersane-i Âmire}

Tersane-i Âmire Osmanlı denizcilik faaliyetlerinin merkez üssüdür. Osmanlı Devleti’nin ilk teşekküllü tersanesi Yıldırım Bayezid tarafından 1390 yllında Bizans'tan kalan tersanenin yerine Gelibolu'da kurulmuştur (Bostan, 2011: 513). İstanbul'un fethinden sonra bir müddet Kadırga Limanı tersane olarak kullanılmış, daha sonraları Haliç’in Aynalıkavak semtinde birkaç gözden ibaret ilk Galata Tersanesi inşa edilmiştir. Yavuz Sultan Selim zamanında Galata'dan Kâğıthane'ye kadar geniş bir alanı kapsayacak şekilde genişletilen Haliç Tersane'si, Osmanlı İmparatorluğunun yıkılışına kadar donanmanın inşai ve idari merkez üssü olmuştur. Yavuz Sultan Selim devrinde başlayan inşa faaliyeti Kanuni Sultan Süleyman döneminde de sürmüştür (Bostan, 1992: 3-4). Daha sonraki dönemlerde de çeşitli ilaveler yapılan tersanenin binaları arasında gözler, mahzenler, kârhâneler, odalar, divanhane, cami, zindan, Tersane-i Âmire Bahçesi ve Kasrı bulunmaktaydı (Bostan, 1992: 3-4; 2011: 514). Seyyid Vehbî’nin eserinde Tersane-i Âmire; konumu ve III. Ahmed döneminde yapılan restorasyon ve ilaveler dolayısıyla yer alırken tersane bölümlerinden divanhane, zindan ve Tersane Kasrı söz konusu edilmiştir.

Donanmâ-yı hümâyûnun mu'zam esbâb-ı şevketdür

O şîrân-ı gazânun gâbıdur Tersâne bogazı

(T. 24/17, 368)

(Tersane Kasrı) Padişah donanmasının en büyük heybet/büyüklük alametidir. O gaza arslanlarının ormanı Tersane boğazıdır.

Tersane Kasrı'nın H. 1139 (M. 1727) yılında yapılan restorasyonu için yazılan bir tarih manzumesinde bulunan bu beyitte kasrın, donanmanın heybetinin en büyük göstergesi olduğu ve gaza arslanı olarak nitelenen donanma mensuplarının/denizci askerlerin yerinin, arslan-orman ilgisi dolayısıyla, ormana benzetilen Tersane boğazı olduğu söylenmiştir. Beyitte Tersane-i Âmirenin konumu, "İstanbul Boğazı’nın Marmara Denizi ă̆zına yakın kesiminde (bulunan)” (Eyice, 1997: 264) Haliç’te olması dolayısıyla Tersane boğazı olarak dile getirilmiştir.

Devlet yeniden kılındı temhîd

Tersâne vü Tophâne tecdîd

(K. 81/21, s. 289)

Devlet yeniden düzenlendi, Tersane ve Tophane yenilendi. 
Sultan III. Ahmed için yazılan bir sıhhatnamenin padişahın övgüsünün yapıldığı bölümünde yer alan bu beyitte onun zamanında devletin yeniden düzenlendiği, Tersane ve Tophanenin yenilendiği söylenmiştir. Beyitte III. Ahmed zamanında Tersane-i Âmire ve Tophane-i Âmirede yapılan ekleme ve tamiratlar kastedilmiştir. 3

\subsection{Divanhane}

Divanhane, Tersane-i Âmirede idari hizmetlerin görüldüğü kaptan paşa, Tersane-i Âmire kethüdası gibi şahısların odalarının bulunduğu binadır. Fatih Sultan Mehmed tarafından yaptırılan ilk divanhaneden sonra Yavuz Sultan Selim devrinde tersane genişletilirken bir de yeni divanhane eklenmiştir (Bostan, 1992: 11). H. 1134 (M. 1722) yllında Tersanede yapılan üç ambarlı kalyonun denize indirme töreninde divanhanenin harap durumunu gören III. Ahmed, bu binanın yıkılarak yerine yenisinin yapılmasını emretmiş ve yeni divanhane binası 1722 yılında tamamlanmıştır (Polat, 1997: 3). Divanda bu yenilemenin söz konusu edildiği bir tarih manzumesi yer almaktadır.

İşte ez-cümle anun mi'mâr-1 lutf u himmeti

Neyledi neyler dahı seyr it hele Tersâne'yi

Eyleyüp bir gün şerefmend-i kudûm-i es'adı

Ol hidîv-i bahr ü berr kalyon-ı kapudâneyi

İtdi manzûr-ı nigâh-1 i'tibâr ol şehriyâr

Kapudan paşalara mahsûs olan kâşâneyi

(T. 26/9-11, s. 370)

İşte özellikle onun iyilik ve yardım mimarı; ne yaptı, ne yapar da seyret Tersaneyi.

O kara ve denizin padişahı kaptan paşa kalyonunu bir gün hayırlı gelişiyle şereflendirip kaptan paşalara özel olan köşke itibar bakışını yöneltti.

Her yirin tecdîd idüp terfi' ü tevsî’ eyledi

Emr idüp yapdurdı bu resm-i şehenşâhâneyi

Tâk-ı eyvân-ı bülendi bükdi Cevza’nun belin

Reşk-i cüftî itdi pür-pîç ebrû-yı cânâneyi

Şimdi oldı pâdişâha lâyı ol devlet-serâ

Şâhbâz-1 şevket işte böyle ister lâneyi

(T. $26 / 13-15$, s. 371 )

Her yerini yenileyip yükseltip genişletti, emredip bu şahlar şahına lâyık planı yaptırdı.

Yüksek divanhanenin kemeri Cevza’nın belini büktü, çifte (kemerin) kıskançlı̆̆ yârin kaşlarını büktü.

O devlet sarayı şimdi padişaha lâyık oldu. Büyüklük/heybet doğanı işte yuvayı böyle ister.

Divanhane binasının tamamlanması üzerine yazllan kıt’a-i kebîrede bulunan bu beyitlerde bir gün kaptan paşa kalyonunu şereflendiren III. Ahmed’in, kaptan paşalara özel köşkü görüp yenilenmesini

Sultan III. Ahmed zamanında Tersane-i Âmire'de yapılan ilave ve tamiratlar şu şekildedir: H. 1116'da (M. 1704/1705) tersane gözlerinden birkaçı leventlerin kışlağı hâline getirilmiş ve tamire muhtaç yerleri yaptırılmış, H. 1120'de (M. 1708/1709) lenger imalatı için yeni bir kârhâne oluşturulmuş, H. 1131'de (M. 1718/1719) Tersane Sarayı'nın has ahır, nalbant odası, sundurma, ahır şadırvanı gibi yapıları tamir edilmiş, H. 1134'te (M. 1721/1722) divanhane yenilenmiş, H. 1139'da (M. 1726/1727) Tersane Kasrı'na eklemeler yapılmış ve Enderun ağaları için bir daire inşa edilmiştir (Abdülkadir Özcan, Yunus Uğur, Baki Çakır ve Ahmet Zeki İzgöer, Târîh-i Râş̧id Ve Zeyli Râsşid Mehmed Efendi-Çelebizâde İsmail Âsım Efendi, c. 2-3, Klasik Yayınları, İstanbul 2013, 729, 799, 1303, 1523; Ertürk, 2013: 344 ). 
emrettiği ve iyilik ve yardım mimarı -İbrahim Paşa olabilir- vasıtasıyla Tersaneyi mamur hâle getirdiği söylenmiştir. Beyitlere göre yenileme çalışmaları kapsamında eskisinden daha yüksek ve geniş bir şekilde inşa edilen bina, kemerinin yüksekliği ve güzelliği ile padişaha layık bir duruma getirilmiştir. Beyitlerde bina kemeri, yükseklik ve güzelliği ile Cevza/İkizler burcu ve sevgilinin kaşlarından üstün tutularak mübalağalı bir şekilde övülmüştür.

Yapdı Sultân Ahmed'ün lutfi bu dîvan-hâneyi

Makdem-i pâk ile nev-bünyâd idüp Tersâne'yi $\quad$ (T. 26/17, s. 371)

Mübarek gelişiyle Tersaneyi yeni (bir) bina hâline getirip Sultan Ahmed’in lütfu bu divanhaneyi yaptı.

Divanhanenin yapımına tarih düşürülen bu beyitte binanın yapımının tamamlanmasının ardından padişahın gelişiyle Tersanenin bütünüyle yeni bir binaya döndüğü söylenmiştir. Beyitte düşürülen tarih H. 1134 (M. 1722)'tür.

\subsection{Tersane zindanı}

Esirlerin ve suçluların konulduğu Tersane-i Âmire Zindanı; etrafı yüksek duvarlarla çevrili ve dışarıdan sadece içindeki binaların çatıları görünen, duvarlarında pencere bulunmayıp ışı̆̆ı tepede bırakılan camlardan alan bir yapıdır (Bostan, 1992: 12). Evliya Çelebi’nin bildirdiğine göre tünel kazılmasını engellemek için yer altı bile kat kat büyük mermerle döşenmiş bu zindandan insanın hiçbir şekilde kurtulması mümkün değildir (Kahraman ve Dağlı, 2014: 378). Eskiden burası genellikle Tersane Zindanı yerine "Tersane" olarak anılmıştır (Onay, 2000: 439). Tersane-i Âmire Zindanı divanda suçluların konulduğu yer olması bakımından söz konusu edilmiş ve "Tersane" şeklinde zikredilmiştir.

Dil-i Vehbî k'ola garkâb yem-i 'isyâna

Müstehakdur bilürem keşmekeş-i hizlâna

Yiri mücrim olanun çünki olur tersâne

Lîk yol vir bana sen bâgçe-i Rızvân'a

Mücrimem eyleme bahr-i keremünden beni dûr

Zevrak-ı mey de çekersem yine ey sadr-ı sudûr

(Müs. 2/5, s. 461)

İsyan denizine batmış olan Vehbi’nin gönlü yalnız başına mücadeleyi hak etmiştir biliyorum. Çünkü suçlu olanın yeri Tersane olur. Ama sen bana Rıdvan bahçesine yol ver. Ey sadrazamlar sadrazamı! Suçluyum, şarap şişesi/kayığı çeksem de beni cömertlik denizinden uzaklaştırma.

Şair, bir müseddeste yer alan bu bentte büyük bir günah olan isyan dolayısıyla Tersane Zindanında tek başına mücadeleyi hak ettiğini dile getirmekle işlediği suçun ağır bir ceza gerektirdiğine işaret etmiştir. Hatta bu cezanın tek başına çekilmesi hücre cezasının kastedildiğini düşündürmektedir. Dolayısıyla bentten Tersane Zindanının koşullarının suçlular için ağır olduğu anlaşılmaktadır. Bentte isyanın ve sadrazamın cömertliğinin çokluğunu ifade etmek için deniz benzetmesi kullanılırken zindanın yeri de bu ilgiyle uyumlu olarak Tersane olmuştur. Bentteki tenasüp "garkâb" ve "zevrak" kelimeleriyle sürdürülmüştür. 


\subsection{Tersane-i Âmire Bahçesi ve Kasr-1 Hümâyûn}

Hükümdarların gezinti yeri olması sebebiyle Has Bahçe olarak da anılan Tersane-i Âmire Bahçesi, ilk defa Fatih Sultan Mehmed tarafından Hasköy'de imar ve iskân edilmiştir. İçinde kasırlar, hamamlar, odalar, sofa, şadırvan, ahır ve benzeri binaların bulunduğu Tersane Bahçesi’nin en meşhur sarayı olan Kasr-ı Hümâyûn (Tersane Sarayı) I. Ahmed devrinde H. 1022 (M. 1613)'de inşa edilmiş (Bostan, 1992: 13), III. Selim devrine kadar yapılan yenileme amaçlı binalar ve ilavelerle büyümüştür (Koçu, 1960: 1611). 17. asrın başlarından itibaren çok defa tamirat geçiren kasır, III. Ahmed devrinde Haliç ve bilhassa buraya dökülen Kağıthane Deresi sevilen bir mesire yeri olduğundan bakımlı tutulmuştur. Kasır, III. Ahmed zamanında ilki H. 1131 (M. 1719) ve ikincisi H. 1139'da (M. 1727) olmak üzere iki tamirat geçirmiştir (Gürün ve diğerleri, 1994: 11-14; Eyice, 1991: 264; Ertürk, 2013: 344). İlk tamirat sarayın has ahır, nalbant odası, sundurma, ahır şadırvanı gibi yapıların tamirini; ikincisi ise saraya yeni birimlerin eklenmesi gibi inşaat faaliyetlerini kapsamaktaydı (Ertürk, 2013: 344). Divanda H. 1139 (M. 1727) yılında yapılan tamiratı konu alan bir tarih manzumesi bulunmaktadır.

Husûsâ bu serây-ı dil-keş-i vâlâ-yı Tersâne
Ki huld olur eger âb u hevâda olsa enbâzı
Misâl-i hâtır-ı 'âşık olup vîrân ü sûzân
Güşâyiş bulmadan me'yûs olmışken der-i bâzı
İdüp tecdîd-i fermân itdi bir sâhil-serâ bünyân
Ki mi'mâr-ı hired oldı esîr-i tarh-ı mümtâzı

Ayrıca bu tersanenin gönül çeken sarayı ki; eğer suyunda ve havasında/ikliminde lakapları olsa Huld cenneti olur.

Âşığın gönlü gibi harap ve yanmış olup kapısı daha açılmadan ümidi kesmişken

Yenilenmesini emredip akıl mimarını seçkin tertibinin esiri edecek kadar güzel bir sahilsaray inşa etti.

Tersane Sahilsarayı'nın restorasyonu için yazılan kıt'a-i kebîrede yer alan bu beyitlerde suyu ve havasıyla Huld cennetine benzetilen Tersane Sarayı'nın âşık gönlü gibi yanmış ve yıkılmış olduğu, padişahın yenilenmesini emretmesi üzerine de hayret uyandıracak güzellikte bir sahilsaray inşa edildiği söylenmiştir.

İdüp ihyâsına himmet kerâmet itdi bî-minnet

Hem itdi cây-ı nüzhet hem nazargâh-ı mühim-sâzı

Hem âb-ı rûy-i sahrâ oldı hem hâk-i leb-i deryâ

Ki mislin görmedi hurşî̀d ü mâhun dîde-i bâzı

Ta'âla'llâh zihî devlet-serây-ı dil-güşâ mevki'

Ki yokdur behcet ü eşrâf ü ra'nâyîde enbâzı

Olur âyîne-i deryâda hüsnin seyr idüp hayrân

Görilmiş mi bakun bu nev-'arûs-ı hacle-i nâzı

İhyasına gayret edip karşılık beklemeksizin bağışta bulundu. Hem ferahlık yeri/iç açıcı bir yer yaptı hem de önemli bir nazargâh/bakılan yer yaptı.

Hem ovanın/çölün yüz suyu oldu hem deniz kenarının toprağı oldu, ki güneş ve ayın açık gözü benzerini görmedi. 
Ne hoş bir yer, ferahlık veren devlet sarayı ki, güzellik, şeref ve hoşlukta eşi yok.

Deniz aynasında güzelliğini seyredip şaşırır. Görülmüş mü, bakın bu naz gerdeğinin yeni gelini?

Yukarıdaki beyitlere göre ise padişah, Tersanenin ihyası için gayret göstermiş; burayı hem iç açıcı hem de seyre değer bir yer yapmıştır. Tersane, güzelliğiyle ovanın/çölün yüz suyu, deniz kenarının toprağı olurken eşsiz güzellikteki sahilsaray da ferahlık veren bir görünüm arz etmektedir. Denizin aynaya benzetildiği son beyitte ise sahilsarayın denize akseden güzelliğinin kendisini bile şaşırttığı söylenerek nergis (Narkisos) hakkındaki efsaneye telmih yapılmıştır.

Bu kasrı eyledi Tersâne'ye hâlet-fezâ-yı nev

Hümâ-sâye Sikender-pâye Sultân Ahmed-i Gâzî

(T. 24/31, s. 369)

Hüma gölgeli ve İskender payeli Gazi Sultan Ahmed bu kasrı, Tersaneye yeni bir hâlet-efzâ (lalesi) yaptı.

Noktalı harflerle tarih düşürülen bu beyitte Sultan III. Ahmed'in, sahilsarayı Tersaneye hâlet efzâ lalesi yaptığı söylenerek sahilsarayın güzelliği dile getirilmiştir. Beyit sahilsarayın restorasyonunun H. 1139 (M.1727) yılında yapıldı̆̆ını göstermektedir.

\section{Osmanlı bahriyesinde kullanılan gemiler}

Osmanlılar; donanmanın teşekkülünden 17. yüzyılın ikinci yarısına kadar kürekli gemiler, 19. yüzyılın ortalarına kadar ise yelkenli gemiler kullanmışlardır (Bostan, 2004: 67). Seyyid Vehbî̀nin eserinde hem kürekli hem de yelkenli gemiler söz konusu edilmiştir.

\subsection{Kürekli gemiler}

Kürekle hareket eden ve yelkeni yardımcı olarak kullanılan gemilere "çekdiri”, "çekdirir" veya "çekdirme" denmekte ve oturak adedine göre çeşitlere ayrılmaktadır. Donanmanın süratli gemilerinden olan (Bostan, 2004: 68, 72; 2007: 107; Uzunçarşılı, 1988: 455) çekdiriler ticarî amaçlı da kullanılmıştır (Süleyman Nutkî, 2011: 54). Divanda Osmanlı donanmasının üstün nitelikli bir unsuru olarak ve Sultan III. Ahmed’in şehzadelerinin sünnet düğününde düğün meydanına getirilmesi bakımından yer alan çekdiri şekil açısından hilale benzetilmiştir.

Felek yanında sandal olamaz ne çekdüriler var

İnanmazsa gelüp tersâneye baksun temâşâya $\quad$ (K. 67/21, s. 251)

Ne çekdiriler var ki, felek yanında sandal olamaz, inanmazsa tersaneye gezmeye gelip görsün.

Kaptan Mustafa Paşa'nın övüldüğü bu beyitte Mustafa Paşa'nın başı olduğu Osmanlı donanmasında bulunan çekdirilerin mükemmelliği yanında feleğin sandal bile sayılamayacă̆ı söylenmiştir.

Gurre mi şeb-i siyehde dâ'ir

Çekdürme midür karada sâ'ir $\quad$ (K. 82/95, s. 305)

Karanlık gecede dolanan bir hilal mi, (yoksa) karada seyreden bir çekdirme mi? 
Bu beyit Sultan III. Ahmed'in şehzadelerinin sünnet düğünü dolayısıyla yazılmış bir kasidede yer almaktadır. Beyit düğün meydanının tasvirine dair beyitlerden biri olup bu meydana getirilen çekdiriye işaret etmektedir. Meydana getirilen çekdirinin yarattığı şaşkınlık bunun gece gökyüzünde dolanan hilal mi, karada yürüyen çekdiri mi olduğunun anlaşılamadığı söylenerek ortaya konmuştur. ${ }^{4}$

\subsubsection{Büyük donanma gemileri}

Firkate, pergende, kalyata, kadırga, baştarda ve mavna büyük donanma gemilerini oluşturmaktadır (Bostan, 1992: 83-87). Divanda bu gemilerden baştarda ve kadırga yer almaktadır.

\subsubsection{Baştarda}

Üst düzey deniz komutanlarının kullandıkları kadırgaların büyük tiplerinden olan savaş gemilerinden biridir. Oturak sayısı 26 ile 36 arasında değişen baştardaların 36 oturaklısına paşa baştardası, 26 oturaklısına ise yarım ya da orta baştarda denmektedir (Pakalın, 1983: 169-170; Bostan, 2007: 107-108). Baştardanın divanda sözü edilen türleri kaptan paşanın bindiği paşa baştardası ile Tersane-i Âmire kethüdasının bindiği orta baştardadır. Paşa baştardası kürekleri, büyüklüğü ve sürati; orta baştarda ise kıç örtüsüyle söz konusu edilmiştir.

Per-i mikzâf ile baştardası geldükce pervâza

Degül kasdum uçurma benzedürler anı 'ankâya

(K. 67/19, s.251)

Baştardası kürek kanadıyla uçsa onu ankaya benzetirler, niyetim boş laf/uçurma değil.

Paşa baştardası baştardaların en büyüğü olup 36 oturaklı, 72 kürekli idi. Boyu 70-72 arşın olan bu gemilerin yaklaşı 800 mürettebatı bulunurdu (Pakalın, 1983: 169-170; Bostan, 1992: 86). Kaptan Mustafa Paşa'nın kaptanlığa getirilmesi dolayısıyla söylenen bir kasidede yer alan bu beyitte paşaya ait baştardanın kürekleri kanada, bu küreklerin hareketiyle yol alan baştarda ise ankaya benzetilmiştir. Baştardanın ankaya benzetilmesinin sebebi ankanın çok süratli uçması ve büyüklüğüdür. Şair, beyitte baştardanın ankaya benzetilmesinden kastının boş laf ya da kâğıttan kuş olmadığını söylerken tevriyeli kullandı̆̆ı "uçurma" kelimesiyle "yelkenli savaş gemilerinden teşkil olunan ince donanmanın en küçük (ve çok süratli) gemisi” (Pakalın, 1983: 541) olan "uçurma”ya da işarette bulunmuştur.

Ol ki fark itmez gören pûşîde-i keştîsini

Atlas-1 gerdun mıdur deryâyi bir hârâ mıdur (K. 71/10, s. 263)

Onun gemisinin örtüsünü gören felek atlası mı, mavi bir ipek midir fark edemez.

Tersane-i Âmire kethüdasına ait baştardaya "orta baştarda" denmiştir (Bostan, 1992: 86). Tersane Kethüdası Ali Mehmed Ağa’ya yazılan bir kasidede yer alan bu beyitte Ali Mehmed Ağa’nın gemisinin örtüsünün felek atlası ml, yoksa mavi renkte ipek bir kumaş mı olduğunun ayırt edilemediği söylenmiştir. Burada bahsedilen örtü Tersane-i Âmire kethüdasına ait baştardanın kıç örtüsüdür. Fakat

$4 \quad$ "Tersane emini Abdullah Efendi’nin kollayıp gözetmesi, Kaptan Süleyman Paşa Hazretleri”nin gayreti ve kimseye duyurulmaması uyarısını meyvesi ve Tersane Kethüdası Musa Paşa’nın işe girişmesiyle yapılmış olan baştarda biçiminde, otuz alt zirâ boyunda, on üç oturakl, üç fenerli bir çektirmeyi çektire çektire düğün meydanına getirip vezirler dairesi yakınında bir yerde hazır bulundurma limanına demir atmışlardı” (Tulum, 2008: 111). 
Osmanlı'da bu örtüler için kullanılan kumaş genellikle çuka/çuha olmuştur.5 Buna göre beyitte bu örtünün ipek olarak zikredilmesi kethüdanın mübalağalı bir şekilde övülmesinden kaynaklanmaktadır.

\subsubsection{Kadırga}

Kadırga, Osmanlı donanmasının çekdiri sınıfına dâhil gemilerinden olup kürek ve yelkenle kullanılırdı. Yirmi beş oturaklı ve kırk dokuz kürekli idi (Pakalın, 1983: 129; Bostan, 1992: 85). Bu gemiler gayet uzun ve dar, su seviyesinde denecek kadar alçak ve oldukça seri gemilerdendi (Uzunçarşıll, 1988: 462). Manevra kabiliyetleri ve fırtınaya tahammül dereceleri de yüksekti. Kalyonların yaygınlaşmasından evvel kadırgalar Osmanlı donanmasının esasını teşkil ederdi (Sertoğlu, 1986: 330) ki, bu 17. yüzyılın sonlarına tekabül etmektedir (Bostan, 2004: 66). Kadırgaların gösterişli ve süslü olanlarına "kaptan paşa kadırgası" veya "kaptan paşa baştardası" denmiştir. Bunlara kaptan paşalar bindiği için bu isim verilmiş ve paşa gemisi olduğunun bir alameti olarak kıç kasaraları üzerinde üçer fener yakılmıştır (Pakalın, 1983: 169-170; 1983: 187, 757). Divanda kaptan paşa hakkındaki bir beyitte üç fenerli kadırgadan söz edilerek bu gemilerin kaptan paşalara ait oluşuna işarette bulunulmuştur.

Eger hurşîd ü mâha şeb-çerâg-ı bahr zamm olsa

Felek anlarla dönse üç fenerlü bir kadırgaya

(K. $67 / 23$, s. 251)

Eğer deniz şeb-çerağı güneş ve aya eklense felek onlarla üç fenerli bir kadırgaya döner.

Kaptan Mustafa Paşa için söylenen bir kasidede bulunan yukarıdaki beyitte güneş ve ay, ışık kaynağı olmaları bakımından fenere teşbih edilmiş ve deniz şeb-çerağının ${ }^{6}$ bunlara eklenmesiyle feleğin üç fenerli bir kadırgaya döneceği söylenerek "kaptan paşa kadırgası"na işaret edilmiştir.

\subsection{2. İnce donanma gemileri}

Esas olarak kürekle hareket eden bazı türlerinde yelken de kullanılan ince donanma gemileri daha çok nehirlerde faydalanılan, donanma denize açıldığında da büyük gemilerin maiyetinde bulunan bir kısmı kayık türünde gemilerdir. Karamürsel, şayka, şahtur, kancabaş, kırlangıç, üstüaçık, işkampoye, tonbaz bu gemilerdendir (Bostan, 1992: 88-94; 2007: 132). Seyyid Vehbî Divanı'nda ince donanma gemilerinden kancabaş söz konusu edilmiştir.

\subsubsection{Kancabaş}

Kancabaş, nehirlere girebilen ve hafif filodan sayılan teknelerdendir. Baş ve kıç kısımları kancaya benzediği için bu adla anılmıştır. 18. yüzyılın başlarında sı̆̆ yerlerde zahire, asker ve mühimmat taşımak için kullanılan kayık türünde bir gemidir (Uzunçarşll, 1988: 457; Bostan, 2007: 135). Divanda bir beyitte şekli ve hızı bakımından yer almıştır.

Muhtasar bir kanca-baş idüp çekerdi altına

Ger hilâle irse dest-i iktidâr-ı rûzgâr

(K. 66/34, s. 247)

\footnotetext{
$5 \quad$ Sadrazam ve kaptan paşa baştardasının çadırı için çuha yanında kemha da kullanılmıştır. Kumaşların rengi ise yeșil ve kırmızıdır. Bkz. İdris Bostan. (1992). Osmanl Bahriye Teşkilâtı: XVII. Yüzyılda Tersâne-i Âmire. Ankara: Türk Tarih Kurumu Yayınları. s. 168; Osmanlılar ve Deniz. İstanbul: Küre Yayınları. s. 109.

$6 \quad$ Şeb-çerag Türkçesi "şimşirek taşı" olan ve geceleyin lamba gibi ışık yayan bir mücevher olmakla birlikte hurafeye göre gâv-i bahrî (deniz öküzü) bazı geceler otlamak için karaya çıktı̆̆ında bu mücevheri ağzından çıarıp otlayacağı yere koyar ve onun aydınlı̆̆ında otlarmış (Onay, 2000: 422; Mütercim Âsım, 2009: 713).
} 
Rüzgârın güçlü eli eğer hilale erişse kısa bir kancabaş yapıp altına çekerdi.

Kaptan Mustafa Paşa'nın övüldüğü bu beyitte kancabaşı şekil açısından hilale benzeten şair, rüzgârın gücünün hilale erişmesi hâlinde kaptanın binmesi için hilali kısa bir kancabaş yapacağını söylemiştir. Kancabaşın şekil açısından hilale benzetildiği beyitten hızlı hareket ettiği anlaşılmaktadır. Ayrıca hilalin kısa/kısaltılmış bir kancabaş olarak tasavvuru mübalağa amacı taşıyabileceği gibi kancabaşların uzun gemiler olabileceğini de akla getirmektedir.

\subsection{Yelkenli gemiler}

Osmanlılar 15. yüzyılın sonlarından itibaren kürekli gemiler yanında yelkenli gemiler de kullanmaya ve inşa etmeye başlamışlarsa da 16. yüzyılda yelkenli gemiler yerine küreklileri tercih etmişlerdir. 17. yüzyllın ortalarında ise yeni bir hamleyle yelkenli gemileri tekrar inşa etmeye ve kullanmaya başlamışlardır. Kalyon, barça, göke gibi gemilerden oluşan (Bostan, 2007: 139-143) yelkenli gemilerden divanda kalyonlar söz konusu edilmiştir.

\subsubsection{Kalyon}

Kalyon, Osmanlı donanmasında yelkenle hareket eden savaş gemilerinin en büyüklerine verilen isimdir (Sertoğlu, 1986: 169). Üç direkli yelkenli bu savaş gemileri 15. asrın sonlarından 17. asrın ortalarına kadar daha çok nakliyede, bundan sonra ise geliştirilmiş savaş gemisi olarak kullanılmıştır (Bostan, 1992: 94). Kalyonlara 17. asrın yarısından sonra isim verilmeye başlanmıştır. Kalyonlar, H. 1093’te (M. 1682) kalyonculuğun ihyasından sonra şadırvan kıçlı, sungur kıçlı, güneş kıçlı, küçük ay kıçlı, zülfikar kıçlı gibi adlarla zikredildiği gibi bunlara tayyâr-ı bahrî, hediyyetülmülk, şehbâz-ı bahrî gibi isimler de verilmiştir (Uzunçarşıll, 1988: 470). Kalyon divanda ham maddesi, şekli, bazı türleri ve Sultan Ahmed'in şehzadeleri için düzenlenen sünnet düğününde dügün meydanına getirilişiyle yer almıştır.

Yanında 'asâ meç taşımak gibi gelürdi

Kalyon nihân olduğını görse 'asâda $\quad$ (G. 210/4, s. 647)

Asada kalyon gizli olduğunu görse yanında asa taşımak meç taşımak gibi gelirdi.

$\mathrm{Bu}$ beyitte gazelin tamamından anlaşıldığına göre aslında zahit eleştirisi yapılmakta ve zahidin asada kalyonun gizli olduğunu görmesi hâlinde yanında asa taşımasının bir kılıç türü olan meç taşımaya eş değer olacağı söylenmektedir. Zahidin zahir ehli oluşuna dair söylenen bu beyte göre kalyon hakkında söylenebilecek şey kalyonun ham maddesinin ağaç/ahşap oluşudur.

Felek aklı başındaysa alup nuh-bâd-ban-ı fülkin

Gelüp ay kıçlu kalyon gibi zamm itsün donanmaya $\quad$ (K. 67/20, s 251)

Felek aklı başındaysa dokuz yelkenli gemisini alıp ay kıçlı kalyon gibi donanmaya eklesin.

Kaptan Mustafa Paşa'nın övüldüğü bu beyitte feleğe, onun kaptan paşalığı döneminde, dokuz yelkenli gemisini alıp ay kıçlı kalyon gibi donanmaya katılması tavsiye edilmektedir. Beyitte kalyon yelkenli bir gemi oluşu ve donanmada da bulunan "küçük ay kıçlı" adında bir türüyle söz konusu edilmiştir.

Eyleyüp bir gün şerefmend-i kudûm-i es’adı 
Ol hidîv-i bahr ü berr kalyon-ı kapudâneyi

İtdi manzûr-ı nigâh-ı i'tibâr ol şehriyâr

Kapudan paşalara mahsûs olan kâş̧âneyi

(T. 26/10-11, s. 370)

O kara ve denizin padişahı, kaptan paşa kalyonunu bir gün hayırlı gelişiyle şereflendirip kaptan paşalara özel olan köşke itibar bakışını yöneltti.

Kaptan paşalar 18. yüzyılın başlarına kadar donanmanın başında denize çıktıklarında paşa baştardasına binerlerdi. Kaptan paşaların 1701-1702 tarihinden itibaren ise savaş zamanlarında baş kapudâne denilen kalyona, sulh dönemlerinde yine baştardaya binmeleri kanun oldu (Uzunçarşıll, 1988: 464). Tersane divanhanesinin yenilenmesi dolayısıyla yazlan bir tarihte yer alan bu beyitlerde padişahın tersaneye gelerek kaptan paşaya ait baş kapudâne denilen kalyonu şereflendirdiği söylenmiştir.

Şimdi bir heybetlü üç anbarlu inşâd itdi kim

Malta’yı zabta giderse kaçup a'dâ yol vire

(T. $47 / 4$, s. 386 )

Şimdi heybetli üç ambarlı yaptı ki, Malta’yı ele geçirmeye giderse düşman kaçıp yol verir/versin

Ta'miyeyle Vehbiyâ târîhin inşâd eyledüm

İndi üç anbarlu kalyon bahre Mevlâ yol vire

(T. 67/6, s. 386)

Ey Vehbi! Tamamlayarak tarihini yaptım/inşa ettim. Üç ambarlı kalyon denize indi, Allah yol versin.

Üç ambarlı kalyon güverteden başka hem palavra, orta kat denilen ikinci kat hem de top ambarı adını taşıyan üçüncü kat ambarlarında top bulunan kalyonlardır (Pakalın, 1983: 556; Sertoğlu, 1986: 353). Yukarıdaki beyitler III. Ahmed zamanında H. 1135'te (M. 1722-1723) yapımı tamamlanan üç ambarlı kalyonun denize indirilmesiyle ilgilidir. Şair, padişahın Malta'yı ele geçirmek için gitmesi durumunda düşmanın kaçarak yol vereceği derecede heybetli bir üç ambarlı kalyon yaptırdığını söylemiş ve bu geminin denize indirilişine tarih düşürmüştür.

Gerdunda kamer mi cilve-peyma

Kalyon mı yürür havâda âyâ

(K. 82/52, s. 301)

Gökte salınan ay mıdır, yoksa havada kalyon mu yürümektedir?

Bu beyit Sultan Ahmed’in şehzadeleri için düzenlenen sünnet düğünü için yazllan kasidede yer almaktadır. Şairin bir taraftan sünnet düğ̈̈nünde sunulan hizmetleri ve yapılan gösterileri dile getirip bir taraftan da bu cemiyete âdeta feleklerin de katıldığını ima ettiği beyitlerden biri olan bu beyitte gökte salınanın ay mı, yoksa havada yürüyen kalyon mu olduğu sorularak aslında şenlik sırasında meydandan geçirilen bir kalyona işaret edilmiştir.7 Bu da donanma unsurlarının şenliklerde, devletin ihtişamını sergilemek için, bir gösteri unsuru olarak kullanıldığını göstermektedir.

Dügünün onuncu gününde ordu ve esnaf alayları yapılırken geçitte yer alan ketenciler düğün meydanına uzunluğu sekiz zirâ, eni ve boyu üçer zirâ olan içi sattıkları mallarla dolu bir kalyon getirmişler. "Yüz kadar gemici neferi akıntıda kürek çeker gibi bu kalyonu düğün meydanına sürüp getirerek ağırlıkları hareket ettirme sanatının ne olduğunu gösterdiler. İçine leventleri ve araç gereçleri eksiksiz olarak yerleştirilmiş, atlastan bayrak ve yelkenleri açlmış bir durumda, düdüğünü çalarak, top ve tüfek atarak ve çeşit çeşit binden fazla tarrakalı fişekleri halk birbirine katarak, şevket 


\section{Bahriye mensupları}

Osmanlı donanma kadrosunu kaptan paşa, donanma ricali, tersane halkı, gemi mürettebatı ve hizmetlileri ile gemilerdeki savaşçllar oluşturmaktadır. Donanma ricali derya beyi, tersane kethüdası, tersane ricali, tersane emini ve maiyeti, tersane ağası, kalyon görevlileri, tersanedeki din görevlileri ile su taşıyıcıları gibi diğer görevlilerden; tersane halkı azaplar ve neccar/marangoz, kalafatçı, pârutıraş, haddad/demirci, meremmetçi/tamirci, tûcger, makaracı, üstüpücü, kumbaracı gibi tersane sanatkârlarından; gemi mürettebatı ve hizmetlileri reis, alatçı, dümenci, yelkenci, gûmi, kürek yapıcısı, kalafatçı, marangoz, topçu gibi mürettebat ile kürekçi ve alatçılardan; savaşçlar ise timarlı sipahiler, kapıkulu askeri (yeniçeriler), cebeciler, topçular ve leventlerden oluşmaktadır (Bostan, 2007: 69-99). Divanda donanmanın bu geniş kadrosundan kaptan paşa, tersane kethüdası ve leventler söz konusu edilmiştir.

\subsection{Kaptan Paşa}

Kaptan paşa (Kaptan-ı derya) Osmanlı bahriyesinin en büyük amiri ve donanmanın başkumandanıdır. Barbaros Hayreddin Paşa'dan itibaren kaptan paşalık beylerbeyi rütbesindeki kişilere verilirken 16. yüzyılın son yarısından itibaren 1867 'de bu unvanın kaldırılışına kadar vezirlere verilmeye başlanmıştır (Uzunçarşıll, 1988: 414; Bostan, 2001: 354). Kalyon dönemine geçilmesinin ardından H. 1113 (M. 1701) tarihli Bahriye Kanunnâmesine göre kaptan paşa derya beylerinin, kapudan, reis ve diğer donanma ricalinin başbuğu olup derya beylerinin faaliyetlerini denetlemekle sorumlu idi. Tersanede iken kendisine ait divanhanede oturan kaptan paşa, donanma ile denize açıldığında paşa baştardasına binerdi. Kaptan paşaların 18. yüzyılın başlarından itibaren barış zamanlarında baştardaya; savaş sırasında başkapudâne denilen büyük kalyona binmeleri, üç fener ve üç bayrak takmaları kanun oldu (Bostan, 2001: 355). Kaptan paşa, başına yalnız sağ tarafı sırmalı şerit bulunan "kallavi" ve arkasına yeşil atlas üzerine samur kaplı dört yenli kürk giyip beline mücevherli hançer takardı (Mahmud Şevket Paşa, 2010: 46). Kaptan paşaların divana yansıyan özellikleri arasında vezir rütbesinde bulunmaları, deniz işlerinde padişah adına ferman yazabilmeleri, Tersanedeki makamlarının divanhane oluşu, kapudâne kalyonu denen bir kalyonlarının bulunması, kıyafetlerinin yeşil renkli olması yer almaktadır.

Gelmemişdür bahre İskender zemânından berü

Böyle lengerlü vezîr-i Cem-vakar-1 rûzgâr $\quad$ (K. 66/15, 246)

Zamanın Cem vakarlı veziri, İskender zamanından beri denize böyle ağır başlı vezir gelmemiştir.

Kaptan Mustafa Paşa'dan söz edilen bu beyitte Mustafa Paşa üstün nitelikleri ile Cem'e benzetilmiş ve denize "salih bir şahsiyet" (Tökel, 2000: 192) olan İskender zamanından beri böyle ağırbaşlı bir vezirin gelmediğini söylemiştir. Burada kaptan paşalarla ilgili dikkat çeken husus bu unvanın vezirlere verilmesidir.

Misâl-i âb-ı tîg ahkâmı cârî berr ile bahre

Revandur mâhdan mâhîye dek fermânı dünyâya

(K. 67/25, s. 252)

denizinin sahili olan adalet köşkünün kıyısına geldiğinde devlet donanması gibi büyük bir şenlikle neşe saçan gösteriler yaptı ve içinde bulunanlar Sultan'in mutluluğu için dua etmek suretiyle elde etmiş oldukları nimete teşekkür borcunu yerine getirdi"(Tulum, 2008: 333). 
Hükümleri kılıç suyu gibi deniz ve karaya akan (kaptan paşanın) fermanı aydan balığa kadar dünyaya yürür.

Kaptan Mustafa Paşa’nın övüldüğü bu beyitte kaptan paşanın hükümlerinin kara ve denizde etkili olduğu ve fermanının aydan balığa kadar geçerli olduğu ifade edilmiştir. Çeliğe su katma uygulamasının da dikkat çektiği beyitte yer alan kaptan paşa-ferman ilgisi kaptan paşaların denizle ilgili işler için padişah namına ferman yazıp tuğra çekmeye yetkili olmasıyla (Uzunçarşıll, 1988: 415) ilgilidir. Hükümlerinin denizler yanında karada da geçerli oluşu ise kaptan paşaların denizlerle ilgili işler dışında “İstanbul Liman, Tersane, Kasımpaşa ve Galata’nın emniyetini sağlamakla görevli (oluşundan)” (Özcan, 2001: 430) kaynaklanmalıdır.

\author{
Eyleyüp bir gün şerefmend-i kudûm-i es’adı \\ Ol hidîv-i bahr ü berr kalyon-ı kapudâneyi \\ İtdi manzûr-ı nigâh-ı i’tibâr ol şehriyâr \\ Kapudan paşalara mahsûs olan kâş̧âneyi \\ Dost u düşmen manzarı şâhân-ı âlem mefhari \\ Mesned-i İskenderî ya'nî bu dîvan-hâneyi \\ Her yirin tecdîd idüp terfí' ü tevsî̀ eyledi \\ Emr idüp yapdurdı bu resm-i şehenşâhâneyi
}

(K. 26/10-13, s. 370)

O kara ve denizin padişahı kaptan paşa kalyonunu bir gün hayırlı gelişiyle şereflendirip kaptan paşalara özel olan köşke itibar bakışını yöneltti.

Âlemin padişahlarının övüncü, İskender'in makamı olan, dost ve düşmanın baktığı bu divanhanenin her yerini yenileyip yükseltip genişletti, emredip bu şahlar şahına lâyık planı yaptırdı.

Divanhane binasının yenilenmesi üzerine yazılan bir kıt'a-i kebîrede bulunan bu beyitlerde, önceki beyitlerden de anlaşıldığı üzere, padişahın bir gün Tersaneye gelip kaptan paşa kalyonunu şereflendirdiği ve kaptan paşalara özel köşkü, yani divanhaneyi görüp binanın yenilenmesini emrettiği, divanhanenin eskisinden daha yüksek ve geniş olarak yapılan yeni hâliyle padişaha lâyık bir duruma geldiği söylenmiştir. Beyitlerde divanhanenin kaptan paşaların makamı olduğu dile getirilmiştir. Beyitte dikkat çeken bir husus da kaptan paşalara ait kalyondur. Padişahlar denize gemi indirilmesi veya başka sebeplerle Tersaneye geldiklerinde hükümdarların oturmasına mahsus büyük bir kalyona çıar ve burada otururlardı (Uzunçarşılı, 1988: 491). Burada padişahın ağırlandığı kalyon, kaptan paşaların savaş zamanında kullandığı kapudâne kalyonudur.

Hümâyı kumrî iden serv-i sebz-i ‘izzetsin
Dıraht-ı şevkete peyvendi-i karâbetsin
Nemâ-girifte-i mâu'l-hayât-ı himmetsin
Sen ol nihâl-i ser-efrâz-ı bâğ-ı devletsin

Ki Hızr'a nâziş ider sâyeni memerr iden âb
(Thm. 2/55, s. 481)

\begin{abstract}
Hümayı kumru yapan yüce yeşil renkli servisin, büyüklük, heybet ağacına akrabalık bağıyla bağlısın. Yardımın hayat suyuna tutulmuşsun. Sen o devlet bahçesinin başını yükselten (benzerlerinden üstün olan) fidanısın ki gölgeni geçit/geçilecek yol yapan su Hızır’a naz eder.
\end{abstract}

Nâbî’nin (ö. 1712) bir kasidesinin tahmisinde yer alan ve Kaptan Mustafa Paşa’nın övüldüğü bu bentte Mustafa Paşa talih kuşu olan hümayı, "eşlerine sadakatleriyle meşhur (olan)" ve "yırtıcı kuşlardan ve 
avcılardan korunmak için servi, söğüt, çınar gibi ağaçları mekân tutan” (Ceylan, 2007: 172), kumruya döndüren yüce yeşil renkli bir serviye benzetilmiş; onun Sadrazam İbrahim Paşa'nın damadı olmasına işaretle heybet ağacına akrabalık bağıyla bağlı olduğu ve bu sebeple yardımın hayat suyuna tutulduğu dile getirilmiştir. Genel olarak Kaptan Mustafa Paşa'nın talihinin açıklı̆̆ının ifade edildiği bentte onun hümayı kumru yapan yüce yeşil renkli bir serviye benzetilmesi baht açıklığına işaret etmek yanında kaptan paşaların kıyafetlerinin yeşil oluşuyla da ilgilidir.

\subsubsection{Kaptan Mustafa Paşa}

"Kaymak" lakabıyla bilinen Mustafa Paşa; Vezir Poçinli İbrahim Paşa’nın oğlu, Kaptan-ı Derya Merzifonlu Mustafa Paşa'nın torunudur. Damad İbrahim Paşa'nın da damadı olan Mustafa Paşa H. 1133’te (M. 1721) kaptan-ı derya olmuştur. Bu görevini katledildiği H. 1143 (M. 1730) senesine kadar sürdürmüştür (Mehmed Süreyya, 1996: 1198, 1200). Divanda Mustafa Paşa'nın, bazı biyografik bilgileri dışında, kaptanlığa getirildiği tarih ile kaptan paşalığı döneminde donanmanın gücü ve tersanedeki gemi inşa faaliyetlerine dair beyitler bulunmaktadır.

Beşâret birle Hâtif didi yaz târîhin ey Vehbî

Efendün Mustafâ Paşa kapudân oldı deryâya

(K. $67 / 34$, s. 252)

Hatif müjdeyle "Ey Vehbi! Tarihini yaz" dedi. Efendin Mustafa Paşa denize kaptan oldu.

Beyitte Mustafa Paşa'nın kaptan olduğu tarihin gaipten gelen bir sesle "Efendün Mustafâ Paşa kapudân oldı deryâya” şeklinde müjdelendiği söylenmiştir. Beyitte verilen tarih H. 1133 (M. 1721)'tür.

Kapudanlık nice yıl yelkenin suya bırakmışdı

Anun eyyâm-ı câhında yine kesb eyledi pâye

(K. 67/33, s. 252)

Kaptanlık pek çok yll yelkenini suya bırakmıştı, onun makamı zamanında/rüzgârında yine rütbe kazandi.

Kaptan Mustafa Paşa hakkındaki bu beyitte daha evvel kaptan paşalığın, gereği gibi yerine getirilmediği için, değerini yitirmişken onun zamanında yeniden değer kazandığı dile getirilmiştir. Beyitte bu görevdeki ehemmiyetsizlik "yelkenini suya indirmek" deyimiyle ifade edilmiştir. Bu deyim kaptan paşa hakkında söylenen bir beyitte, denizcilikle ilgili unsurları barındırması bakımından, özellikle tercih edilmiştir. Beyitteki bu tavır "rüzgâr" (Devellioğlu, 1999: 244) anlamı da bulunan "eyyâm" kelimesinde de sürdürülmüştür.

Felek aklı başındaysa alup nuh-bâd-ban-ı fülkin

Gelüp ay kıçlu kalyon gibi zamm itsün donanmaya

Felek yanında sandal olamaz ne çekdüriler var

İnanmazsa gelüp tersâneye baksun temâşâya

(K. 67/20-21, s. 251)

Felek aklı başındaysa dokuz yelkenli gemisini alıp ay kıçlı kalyon gibi donanmaya eklesin.

Ne çekdiriler var ki, felek yanında sandal olamaz, inanmazsa tersaneye gezmeye gelip görsün.

Kaptan Mustafa Paşa'nın övüldüğü bu beyitlerin ilkinde feleğe, onun kaptan paşalık yaptı̆̆ı dönemde, dokuz yelkenli gemisini alarak ay kıçlı kalyon gibi donanmaya katılması tavsiye edilmektedir. 
İkincisinde ise Mustafa Paşa'nın başı olduğu Osmanlı donanmasında bulunan çekdirilerin mükemmelliği yanında feleğin sandal bile sayılamayacağı söylenmiştir. Beyitlerde Mustafa Paşa zamanında Osmanlı donanmasının gücü, o dönemde donanma bünyesinde bulunduğu anlaşılan ay kıçlı kalyon ile Tersanede inşa edildiği söylenen emsalsiz çekdiriler vasıtasıyla dile getirilmiştir.

\subsection{Tersane kethüdası}

Bahriye ricalinden olan Tersane kethüdası, kaptan paşadan sonra Tersanenin birinci hâkimi olup Tersanenin inzibat ve disiplinini temin ederdi. Tersane kethüdası orta baştardaya binerdi (Uzunçarşıll, 1988: 427; Bostan, 2007: 77; 1992: 86). Divanda unvan olarak tersane kethüdası geçmemekle birlikte kethüda olarak zikredilen Ali Mehmed Ağa ile ilgili manzumelerde denizcilik terimlerinin kullanılması ve kendisine ait bir gemiden söz edilmesi onun tersane kethüdası olduğunu düşündürmektedir. Divandan Sadrazam İbrahim Paşa'nın damadı olduğu anlaşılan Ali Mehmed Ağa özelinde tersane kethüdalığı hakkında söylenebilecek şey, donanmada kendisine tahsis edilen bir gemisi bulunması ve kaptan paşanın emri altında olmasıdır.

Genc-i bâd-âverde-i Şeh Hüsrev-i Pervîz mi

Yohsa keştî-i cenâb-ı Hazret-i Aga mıdur

(K. 71/6, s. 262)

Hüsrev Perviz’in bad-averd hazinesi mi yoksa saygıdeğer Ali Mehmed Ağa’nın gemisi midir?

Kethüda Ali Mehmed Ağa hakkındaki bir kasidenin hilalle ilgili çeşitli tasavvurların yer aldığı teşbib bölümünde yer alan bu beyitte gökte görünen hilalin Hüsrev Perviz'in genc-i bâd-averd hazinesi mi, yoksa Ali Mehmed Ağa'nın gemisi mi olduğunun anlaşlamadığı dile getirilmiştir Hilalin, kethüdanın cömertliğine işaret etmek suretiyle İran hükümdarlarından Hüsrev Perviz’in hazinelerinden biri olan "genc-i bâd-âverd" (Tökel, 2000: 179) ile ilişkilendirildiği beyitte hilal şekil açısından da kethüdanın gemisine benzetilmiştir.

Hidmet itdügi vezîr ol rütbe gevher-pâşdur

K’ana nisbet eski paşalar meger paşa mıdur $\quad$ (K. 71/8, s. 262)

Hizmet ettiği vezir o derece cevher saçar ki, ona kyyasla diğer paşalar paşa mıdır?

Aynı kasidede yer alan bu beyitte ise kethüdanın hizmet ettiği vezirin cömertliği bol miktarda cevher saçtığı söylenerek dile getirilmiş ve unvanı "paşa" olarak zikredilen bu vezirin kendinden önce gelen paşalardan daha cömert olduğu ifade edilmiştir. Kethüda-paşa ilişkisi beyitte sözü edilen vezirin kaptan paşa olduğunu, dolayısıyla kethüdanın kaptan paşanın hizmetinde bulunduğunu göstermektedir.

\subsection{Levent}

Önceleri "asker, harbe kadir insan", daha sonra "yiğit ve gözünü budaktan sakınmayan adam" manasında kullanılan levent tabiri, denizcilikte "korsan ve korsan reisleriyle birlikte faaliyette bulunan gözü pek, yiğit ve güçlü kuvvetli denizciler"i, karada da "çift bozan, yurdunu terk edip serseriyane dolaşan, bu yüzden geçimini bedenî gücü ve gözünün pekliği yoluyla temin eden kimseler” i ifade etmiştir (Cezar, 2013: 15). 15. asrın sonlarıyla 16. asırda Türk korsan gemilerindeki denizcilerden Osmanlı donanması hizmetine girmiş olan muharip askerlere levent denmiştir (Uzunçarşıll, 1988: 479-480). Bu askerler; bir geminin inzibat, disiplin ve harp gücü yönünden hayati önem taşımakta idi. Gemiler içinde 
tüfek menzilinde tüfeklerle, düşman gemilerine yanaşıldığında ise, pala ve kılıçlarla muharebe eden deniz leventleri, gerektiğinde kara savaşlarında da kullanılırdı (Cezar, 2013: 127, 130). Leventlerin reislerine "şahlevend" (Uzunçarşıll, 1988: 481), İstanbul'da tersanede oturanlarına "yerli levend" denilirdi. Bunların Kasımpaşa'da kışlaları vardı (Cezar, 2013: 134). İdarenin zayıf olduğu ve çeşitli sıkıntıların mevcut olduğu yıllarda soygun ve tecavüz gibi disiplinsiz ve edepsiz davranışları sebebiyle leventlik H. 1189 (M. 1775) senesinde ismen kaldırılmış; 19. yüzyll başlarında yavaş yavaş ilga edilmiştir (Cezar, 2013: 128-129; İlgürel, 2003: 150). Leventler divanda toplum düzenine aykırı davranışları, hükümdarın maiyeti altında bir askerî sınıf olmaları, kendileriyle özdeşleşen bazı özellikleri ve kıyafetleri ile yer almıştır.

Kadeh-nûşân-ı 'aşkun istemezler 'ırz u nâmûsı

Fakat tab'-1 levendâne dil-i âşüfte isterler

(G. 39/5, s. 539)

Aşk kadehi içenler ırz ve namusu istemezler; ama leventçe bir tabiat, divane gönül isterler.

Beyitte aşk kadehini içen kişilerin ırz ve namusu bir tarafa bırakıp leventçe bir tabiat ve delicesine seven bir gönül istedikleri dile getirilirken leventlerin gözü pekliği ve Osmanlı toplumunda huzursuzluğa neden olan davranışları kastedilmiştir. Toplum düzenine aykırı, sıra dışı tavırları bakımından âşıklar ile leventler arasında ilgi kurulmuştur.

Var mı haberün söyle meded ey dil-i şeydâ

Kimdür o levendâne-reviş tâze kimündür

(Kt. 10/1, 684)

İmdat, ey deli gönül! Haberin var mı söyle, o leventçe gidişli taze kimdir, kimindir?

Klasik Türk şiirinde şairler, sevgilinin yürüyüşü ile "levendâne yürüyüş" arasında bazen süratli ve hafif bir gidiş, bazen de kabadayı tarzı yürüyüş bakımından benzetme ilgisi kurmuşlardır (Koncu, 2010: 428). Beyitte şair/âşık, leventçe bir yürüyüşe sahip olan yeni yetmeyi (sevgili) görünce hayranlığını onu gönlünden soruşturarak ifade etmektedir. Burada taze sevgilinin levendâne yürüyüşüyle kastedilen süratli ve hafif bir yürüyüş olmalıdır.

Yâ Rab o şeh levendine sâhib-kırân olur

Kanda çıarsa nîze-i rümmânî kan olur $\quad$ (K. 36/39, s. 161)

Yâ Rab! O şeh levendine/şehlevendine başarılı bir hükümdar olur. Nar renkli mızrağını nerde çıkarsa kan olur.

Tevriyeli kullanımlarıyla "şeh-levend", "sahib-kıran", "nîze-i rümmânî” lalelerine de işaret edilen beyitte istiare yoluyla hükümdar olarak zikredilen sevgilinin, levent olarak nitelenen âşığa başarılı bir hükümdar olduğu ve nar renkli mızrağını nerede çıkarsa kan olduğu söylenmiştir. Farklı şekillerde yorumlanmaya imkân veren söz dizimsel bir yapıya sahip olan beyitte sevgilinin/hükümdarın maiyeti altındaki levende başarılı bir hükümdar olması onun iyi bir savaşçı olmasıyla açılanabileceği gibi âşığına eziyet etmesi şeklinde de değerlendirilebilir. İlk anlam leventlerin padişaha tabi olması, ikinci anlam ise zaman zaman taşkınlıklarda bulunan leventlere uygulanan yaptırımları akla getirmektedir. Beyitte dikkati çeken bir husus da beyitteki söz diziminin hükümdarla maiyet ilişkisi kurulan kişinin leventlerin başı olan "şehlevend" şeklinde anlaşılmasına imkân vermesidir. 
Başında nice dil-âşüftenün yanar âteş

Serindeki o levandâne âl-1 şâlinden
(G. 172/4)(621/4)

Başındaki o leventçesine kırmızı şalından, pek çok meftunun/gönülden vurgun olanın başında ateş yanar.

Beyitte sevgilinin leventler gibi başına sardığı şalın kırmızısından pek çok âşığın başında ateş yandığı söylenmiştir. Şair sevgiliye meftun olmuş kişilerin başındaki aşk ateşini, sevgilinin leventler gibi başına sardığı kırmızı şalla ilişkilendirmiştir. Kaynaklara bakıldığında leventlerin kıyafetlerinin yüzyıllara ve leventlerin kendi içindeki rütbe ve sinfflara göre değişiklik gösterdiği görülmektedir. Buna göre 16. asırda tüfekendaz leventler burma sarı̆̆ı andıran bir sarık giyerken levent acemi oğlanının başlı̆̆ı enderun delikanlılarının başlıklarına benzemektedir (Sevin, 1990: 87-88). Buna karşllık Mahmud Şevket Paşa tüfekçi leventlerin başlarına İtalyan baratalarına benzer kırmızı bir barata taktıklarını, tüfekçi leventler arasında bulunan ve "levend-i Rûmî" denilen leventlerin ise başlarına yemeni sardıklarını bildirmektedir (2010: 91). Mehmet Zeki Pakalın ise levendlerin İtalyan baratalarına benzer kırmızı ve üstüne yemeni sarılan bir külah taktıklarını belirtmiştir (1983: 359). Bu değiş̧kenlik göz önüne alındığında leventlerin başlarına veya külahlarına yemeni yerine şal sarmaları muhtemel gözükmektedir. ${ }^{8} \mathrm{Bu}$ şalın rengi ise kırmızıdır.

\section{Donanmanın denize/sefere çıkması}

Osmanlı donanmasının ilkbaharda denize çıarılması uygulaması II. Bayezid zamanından 19. asır ortalarına kadar devam etmiştir. Sahilleri yabancı devletler ve korsanların taarruzundan koruma amaçlı bu uygulama önceleri Akdeniz'le sınırlıyken 17. asır başlarından itibaren Karadeniz için de geçerli olmuştur. Osmanlı donanmasının denize çıkması teşrifat ve merasim dairesinde gerçekleşirdi. Her sene kadırga çekdirilerinden birinin baştarda-i hümâyûn olmak üzere donatılması ve alay göstermesi, padişahı selamlamak üzere top atışları yapılması bu merasimler dâhilindedir (Uzunçarşıllı, 1988: 437440). Donanmanın denize çıkma merasimleri yanında seferden dönüşünde ya da bazen sefere çıkışında havai fişekler, top ve tüfekler atılarak "derya donanması" denilen ışıklı gösteriler yapılırdı (Sakaoğlu ve Akbayar, 1999: 37-38). Divanda Osmanlı donanmasının denize/sefere çıkışı sırasında yapılan gösterilere/merasime ve bunların ihtişamına işaret edilen bir beyit bulunmaktadır.

Çıkdı deryâ-yı sefid subha fülk-i âfitâb

Bir donanma ile kim hayret-disâr-ı rûzgâr

(K. 66/3, s. 245)

Güneş gemisi sabahın beyaz/ak denizine zamanı/feleği hayretler içerisinde bırakan bir donanmayla çıtı.

Bu beyit Kaptan Mustafa Paşa için yazılmış bir kasidede yer almaktadır. Güneşin donanmanın bir unsuru olarak gemiye teşbih edildiği, sabahın ise aydınlı̆̆ından kinayeyle ak deniz/Akdeniz olarak zikredildiği beyitte güneşin sabahın ak denizine ışıklı gösterilerle çıkarak feleği hayretler içerisinde bıraktığı söylenmiştir. Beyit Osmanlı donanmasının sefere çıkışı sırasında yapılan derya donanmalarına işaret etmekle birlikte "deryâ-yı sefid" terkibinin "Akdeniz"i, "donanma”nın da Osmanlı donanmasını karşılayacak şekilde tevriyeli kullanımı donanmanın her sene ilkbaharda denize çıkarılması uygulamasını da akla getirmektedir.

8 "Kalyoncular, yelkenli gemiler devrinin bahriye askeri kadimden beri başlarına şal saragelmişlerdi" (Koçu, 1969: 214). 


\section{Gemilerin denize indirilmesi}

Gemiyi denize indirme merasiminde Kanuni Sultan Süleyman zamanından beri padişah bizzat bulunurdu. Gemi denize indirilmeden şeyhülislam dua eder ve Fatiha okunup dua bitirildiğinde geminin yanlarındaki direkler alınıp gemi kızakla denize indirilirdi. Her gemi inişinden sonra kurbanlar kesilir (Uzunçarşıll, 1988: 490-491) ve denize indirilen gemiye isim verilirdi. Merasim sonunda âdet olunduğu üzere hilatler giydirilir ve hediyeler verilirdi (Batmaz, 2007: 164-166). Divanda H. 1134 (M. 1721/1722) ve H. 1135 (M. 1722/1723) yllarında iki kalyonun denize indirilişini konu alan iki manzume yer almaktadır. Bunlarda geminin denize indirilişi sırasında padişahın hazır bulunuşu ve dua uygulaması söz konusu edilmiştir.

Ne kalyon inmede bir kimsenün tekâsüli var
Ne kalyonun da nüzûl itmede ta'allüli var
Çoka atasını ister ki ide pây-endâz
Biraz efendüme nâz itse de tahammüli var

$\mathrm{Ne}$ kalyonun inmesinde bir kimsenin tembelliği var, ne de kalyonun aşağı inmede bahanesi/kaçınması var.

Pâyendâz/yolluk yapmak için çuha bahşişini ister. Efendime biraz nazlansa da tahammülü var.

Bu beyitler H. 1135 (M. 1722/1723) yllında yapımı tamamlanan üç ambarlı kalyonun denize indirilişi sırasında kalyonun arka tarafına bağlı halatların sökülüp etrafına konan direklerin alınışının ardından 10-15 metre kadar ilerleyip durması dolayısıyla Seyyid Vehbî tarafından o sırada söylenmiştir (Özcan ve diğerleri, 2013: 1325). Seyyid Vehbî bu duruma şairane bir sebep bulmuş ve üç ambarlı geminin denize inmek için padişaha naz yaptığını, bahşiş olarak pâyendâz (yolluk) yapmak amacıyla çuha istediğini söylemiştir. Buna göre beyitten gemilerin denize indirilmesi merasiminde padişahın bulunduğu anlaşılmaktadır.

Şimdi bir heybetlü üç anbarlu inşâd itdi kim

Malta'yı zabta giderse kaçup a'dâ yol vire

İndürürken seyr idüp keştî-nişînân-ı felek

Bir agızdan didiler Allah Ta’âlâ yol vire

Ta'miyeyle Vehbiyâ târîhin inşâd eyledüm

İndi üç anbarlu kalyon bahre Mevlâ yol vire

(T. 47/4-6, s. 386)

Şimdi heybetli bir üç ambarlı yaptı ki, Malta'yı ele geçirmeye giderse düşman kaçıp yol verir/versin

Felek yolcuları gemi denize indirilirken bakıp bir ağızdan dua ettiler, Allah yolunu açık etsin.

Ey Vehbî, tamamlayarak tarihini yaptım/inşa ettim. Üç ambarlı kalyon denize indi, Allah yol versin.

Yukarıdaki beyitlerde padişahın Malta'yı ele geçirmek için gitmesi durumunda düşmanın kaçarak yol vermesine sebep olacak derecede heybetli bir üç ambarlı kalyon yaptırdığı; felek yolcularının gemi denize indirilirken geminin yolunun açı olması için hep birlikte dua ettikleri söylenmiş ve bu geminin denize indirilişine tarih düşürülmüştür. III. Ahmed zamanında H. 1134'te (M. 1721/1722) yapımı tamamlan üç ambarlı kalyonun denize indirilmesiyle ilgili olan bu beyitler geminin denize indirilişi sırasında dua edilmesi uygulamasını hatırlatmaktadır. 


\section{Sonuç}

Sultan III. Ahmed ve I. Mahmud dönemlerinin pek çok gelişmesini eserine yansıtan Seyyid Vehbî, Osmanlı Bahriye Teşkilatıyla ilgili hususlara da şiirlerinde yer vermiştir. Tersane-i Âmirede yapılan restorasyonlar, gemi inşası ve atama gibi gelişmelerden oluşan bu hususlar Lale Devri'nde gerçekleşmiştir. Daha çok tarih ve kasidelerde konu edilen bahriyeye ait gelişmeler arasında Tersane-i Âmiredeki divanhane ve Tersane Kasrı'nın restorasyonu, iki adet üç ambarlı kalyonun denize indirilişi ve Kaptan Mustafa Paşa'nın kaptanlığa getirilişi yer almaktadır. Divanda sözü edilen bahriye mensupları ise Kaptan Mustafa Paşa ve Tersane Kethüdası Ali Mehmed Ağa'dan ibarettir. Hem Kaptan Mustafa Paşa hakkındaki hem de donanma bünyesindeki gemilerle ilgili beyit ve bentler o dönemde Osmanlı donanmasının oldukça güçlü olduğu izlenimini uyandırmaktadır. Bunlar dışında divanda Tersane-i Âmirenin bölümlerinden zindan; bazı nitelikleri, türleri, kullanım alanları ile o dönemde Osmanlı bahriyesinde bulunan baştarda, kadırga, kancabaş ve kalyon gibi gemiler; gemilerin denize indirilme merasimleri sırasındaki bazı uygulamalar, donanmanın denize/sefere çıkışı sırasında yapılan gösteriler/merasimler, yetkilerinden kıyafetlerine kadar çeşitli özellikleriyle kaptan paşa, tersane kethüdası ve leventlere dair beyit ve bentler bulunmaktadır. Divanda ayrıca denizcilikle ilgili pek çok terim ve tabire de yer verilmiştir. Tüm bu unsurlarla ilgili kullanımlar genellikle donanmayla ve donanma mensubu kimselerle ilgili manzumelerde yer almıştır. Çoğunlukla övgü maksatlı manzumelerde sözü edilen donanmaya ait kişi, unsur ve hususiyetler beyit ve bentlerde mübalağalı bir biçimde ve bu mübalağaya imkân verecek benzetme ilgileriyle yer almıştır. Ayrıca şair, deniz ve denizcilikle ilgili sözcükleri bir arada kullanarak tenasüp oluştururken tevriye yoluyla da sözcüklerin söz konusu alana ilişkin anlamlarını çağrıştırarak beyit ve bentlerde tam bir uyum ortaya koymuştur.

\section{Kaynakça}

Batmaz, Ş. (2007). Tersâne-i Âmire'de Gemilerin Denize İndirilme Merasimi, Atatürk Üniversitesi Sosyal Bilimler Enstitüsü Dergisi, c. 10, sy. 9, ss. 157-176.

Bostan, İ. (1992). Osmanlı Bahriye Teşkilâtı: XVII. Yüzyılda Tersâne-i Âmire, Ankara: TTK.

Bostan, İ. (2001). "Kapudan Paşa”, İslâm Ansiklopedisi, c. 24, İstanbul: Türkiye Diyanet Vakfı.

Bostan, İ. (2004). Kadırgadan Kalyona XVII. Yüzyılın İkinci Yarısında Gemi Teknolojisinin Değişimi, Osmanlı Araşttrmaları, sy. 24, ss. 65-86.

Bostan, İ. (2007). Osmanlllar ve Deniz, İstanbul: Küre.

Bostan, İ. (2011). “Tersane”, İslâm Ansiklopedisi, c. 40, İstanbul: Türkiye Diyanet Vakfi.

Ceylan, Ö. (2007). Kuşlar Dîvânı Osmanlı Şiir Kuşları, İstanbul: Kapı Yayınları.

Cezar, M. (2013). Osmanlı Tarihinde Levendler, Ankara: Türk Tarih Kurumu Yayınları.

Devellioğlu, F. (1999). Osmanlıca-Türkçe Ansiklopedik Lûgat, Ankara: Aydın Kitabevi.

Ertürk, V. (2013). XVII. Ve XVIII. Yüzyıllarda Osmanlı Sultanlarının Bir Eğlenme Ve Dinlenme Mekânı Olarak Tersane Bahçesi, Tarih Okulu Dergisi, sy. 15, ss. 91-125.

Eyice, S. (1991). “Aynalıkavak Sarayı”, İslâm Ansiklopedisi, c. 4, İstanbul: Türkiye Diyanet Vakfi.

Eyice, S. (1997). "Haliç”, İslâm Ansiklopedisi, c. 15, İstanbul: Türkiye Diyanet Vakfı.

Gencer, A. İ. (1991). "Bahriye” (Osmanlı Dönemi), İslâm Ansiklopedisi, c. 4, İstanbul: Türkiye Diyanet Vakfi.

Gürün, A., Öncü, E., Yılmaz, Y., Ulugergerli, F. (1994). Aynalı Kavak Kasrı, İstanbul: TBMM Millî Saraylar Daire Başkanlığı.

İlgürel, M. (2003). “Levent” İslâm Ansiklopedisi, c. 27, İstanbul: Türkiye Diyanet Vakfı. 
Kahraman, S. A. ve Dağlı, Y. (2014). Günümüz Türkçesiyle Evliya Çelebi Seyahatnâmesi, 1. Kitap, c. 2, İstanbul: YKY.

Koçu, R. E. (1960). “Aynalı Kavak Sarayı”, İstanbul Ansiklopedisi, c. 3, İstanbul: Neşriyat K.Ş.

Koncu, H. (2010). Bir Kelimenin İzinde: Klasik Türk Şiirinde "Levend” Üzerine Bazı Düşünceler, Turkish Studies International Periodical For The Languages Literature And History Of Turkish Or Turkic, 5/3 Summer, ss. 421-446, www.turkishstudies.net.

Mahmud Şevket Paşa (2010). Osmanlı Teşkilat ve Kıyafet-i Askeriyesi, Ankara: Türk Tarih Kurumu.

Mehmed Süreyya (1996). Sicilli Osmanî, haz. Nuri Akbayar, c. 4, İstanbul: Tarih Vakfı Yurt.

Mütercim Âsım Efendi (2009). Burhân-ı Katı, İstanbul: TDK.

Onay, A. T. (2000). Eski Türk Edebiyatında Mazmunlar ve İzahı, Ankara: Akçağ.

Özcan, A. (2001). “Karakol”, İslâm Ansiklopedisi, c. 24, İstanbul: Türkiye Diyanet Vakfı.

Özcan, A., Uğur, Y., Çakır, B., İzgöer, A. Z. (2013). Târîh-i Râşid Ve Zeyli Râşid Mehmed EfendiÇelebizâde İsmail Âstm Efendi, c. 2, İstanbul: Klasik.

Özcan, A., İzgöer, A. Z., Uğur, Y., Çakır, B. (2013). Târîh-i Râşid Ve Zeyli Râşid Mehmed EfendiÇelebizâde İsmail Âsım Efendi, c. 3, İstanbul: Klasik.

Pakalın, M. Z. (1983). Tarih Deyimleri Ve Terimleri Sözlüğü, c.1-2-3, İstanbul: Millî Eğitim Basımevi.

Polat, M. (1997). Kuzey Deniz Saha Komutanh̆ğı Karargâh Binası: Bahriye Divanhanesi, İstanbul: Deniz Basımevi.

Sakaoğlu, N. ve Akbayar, N. (1999). Binbir Gün Binbir Gece/Osmanl’dan Günümüze İstanbul'da Eğlence Yaşamı, Y.y.: Denizbank.

Sertoğlu, M. (1986). Osmanl Tarih Lûgat, İstanbul: Enderun Kitabevi.

Sevin, N. (1990). On Üç Asırlık Türk Kıyafet Tarihine Bir Bakış, Ankara: Kültür Bakanlı̆̆ı.

Süleyman, N. (2011). Kamûs-i Bahrî, İstanbul: Türkiye İş Bankası Kültür.

Tökel, D. A. (2000). Divan Şiïrinde Mitolojik Unsurlar (Şahıslar Mitolojisi), Ankara: Akçă̆.

Tulum, M. (2008), Sûrnâme Sultan Ahmet’in Düğün Kitabı, İstanbul: Kabalcı.

Uzunçarşıll, İ. H. (1988). Osmanlı Devletỉnin Merkez Ve Bahriye Teşkilâtı, Ankara: Türk Tarih Kurumu. 